\title{
HYGROSCOPICITY OF OPTICAL GLASSES AS AN INDICATOR OF SERVICEABILITY
}

\author{
By Donald Hubbard
}

ABSTRACT

Several modifications of a powder-hygroscopicity method have been tried as a rapid means of determining the serviceability of optical glasses, i. e., their ability to maintain a clear polished surface under normal conditions of service. The method has been applied to a wide variety of glasses, and it shows the typical optical glasses in common use to be much less hygroscopic than the average commercial sheet and container glasses. In fact, many of the optical glasses even compare favorably with the better chemical laboratory wares, such as Pyrex, Tamworth, and Kimble N-51-a. This grouping of these glasses of such very dissimilar chemical durabilities serves well to emphasize that the capacity of a glass to maintain a clear surface upon exposure to the atmosphere, and its chemical durability as conventionally determined are two inherently different properties. A comparison of the hygroscopicity values of the Corning 015 electrode glass with those of the optical and chemical ware glasses whose electrode capacity is very poor suggests strongly that the $\mathrm{pH}$ response of a glass is primarily a function of its hygroscopicity. Tests made on a limited number of glasses of the binary series $\mathrm{Na}_{2} \mathrm{O}-\mathrm{SiO}_{2}, \mathrm{~K}_{2} \mathrm{O}-\mathrm{SiO}_{2}, \mathrm{Li}_{2} \mathrm{O}-\mathrm{SiO}_{2}$, and $\mathrm{PbO}-\mathrm{B}_{2} \mathrm{O}_{3}$ appear to reflect some of the critical compositions of the respective phase equilibrium diagrams.

CONTENTS

Page

I. Introduction

II. Experimental procedure

III. Results and discussion

1. Glasses of four binary systems

(a) $\mathrm{Na}_{2} \mathrm{O}-\mathrm{SiO}_{2}, \mathrm{~K}_{2} \mathrm{O}-\mathrm{SiO}_{2}, \mathrm{Li}_{2} \mathrm{O}-\mathrm{SiO}_{2} \ldots \ldots$

(b) $\mathrm{PbO}-\mathrm{B}_{2} \mathrm{O}_{3}$ glasses

2. Comparison of some typical optical and other commercial glasses_...

IV. Conclusions

V. References

\section{INTRODUCTION}

The serviceability of optical glasses, namely, the ability to maintain a clear polished surface under normal service conditions, is too often confused with the general subject of the "chemical durability" of glasses. However, as some of the common optical glasses are known to possess poor chemical durability over a wide range of conditions [1], ${ }^{1}$ but still render excellent service, it is evident that many of the methods

\footnotetext{
${ }^{1}$ Figures in brackets indicate the literature references at the end of this paper.
} 
proposed for determining chemical durability [2] throw little or no light on the problem of serviceability. By far the largest percentage of optical glasses are exposed to the air throughout their life of service. Of the chemical constituents in the atmosphere that can affect glasses adversely, all of them generally react through an ionizing medium, of which water is the most familiar and one which is always present. From these simple considerations, general experience [3] and a limited quantity of contradictory data on the adsorption of water by glass [4], it appears probable that the hygroscopic nature of an optical glass is the primary factor with which serviceability is concerned.

\section{EXPERIMENTAL PROCEDURE}

The quantity of water vapor "sorbed" ${ }^{2}$ [5] on a flat polished surface by many glasses is so slight that its magnitude cannot be readily determined by means of the ordinary analytical balance. In order to increase the exposed surface sufficiently to obtain adequate sensitivity, the glasses were crushed in a steel mortar and passed through a No. 150 sieve, $0.104-\mathrm{mm}$ opening. A known quantity, approximately $1.5 \mathrm{~g}$, of this powder dried at $110^{\circ} \mathrm{C}$ was then exposed in a shallow weighing bottle to controlled humidity conditions and the increase in weight obtained.

Several modifications of the exposure were tried:

1. A limited number of glasses of the binary series, $\mathrm{Na}_{2} \mathrm{O}-\mathrm{SiO}_{2}$, $\mathrm{K}_{2} \mathrm{O}-\mathrm{SiO}_{2}$, and $\mathrm{Li}_{2} \mathrm{O}-\mathrm{SiO}_{2}$, were exposed in a glass desiccator vessel, the base of which was filled with distilled water. A uniform high humidity within this chamber was maintained by means of an aspirator drawing air through a Milligan gas-washing bottle filled with distilled water.

2. A set of glasses of the $\mathrm{PbO}-\mathrm{B}_{2} \mathrm{O}_{3}$ series were exposed to 98 -percent relative humidity obtained by a saturated solution of $\mathrm{CaSO}_{4} \cdot 2 \mathrm{H}_{2} \mathrm{O}^{3}$

3. A number of characteristic commercial glasses, including three typical optical glasses, were exposed to 95 -percent relative humidity maintained by a saturated solution of $\mathrm{Na}_{2} \mathrm{HPO}_{4} \cdot 12 \mathrm{H}_{2} \mathrm{O}{ }^{3}$

In procedures 2 and 3 the humidity chamber was placed in an air bath thermostated at $25^{\circ} \mathrm{C}$, and the atmosphere in the chamber itself was circulated by means of a small fan mounted in the ground-glass cover.

To make comparisons between glasses of different densities, the values are reported in terms of water sorbed per calculated equal surface exposed, i. e., water sorbed per cubic centimeter of powder, or stated in terms of known factors, water sorbed times density divided by weight of sample.

2 Following the suggestion of McBain, the term "sorption" is used to express the results, regardless of the mechanism manifested. However, it is helpful in interpreting the data to remember that if equilibrium is not attained quickly one is not dealing with pure adsorption but also with a solution of the vapor in the interior of the solid (absorption) or an ordinary chemical reaction [6, p. 109].

8 Although the relative humidities obtained by means of saturated salt solutions are not considered very reliable, they furnish an easy means of comparing the hygroscopicities of glasses on a relative basis. Causes of uncertainties lie in the difficulty of obtaining equilibrium rapidly and also in the sudden ehanges in realtive humidity arising at the moment a solution forms a crust over the surface. 


\section{RESULTS AND DISCUSSION}

\section{GLASSES OF FOUR BINARY SYSTEMS}

(a) $\mathrm{Na}$

The data plotted in figures 1,2 , and $3^{4}$ show the water sorbedpercentage composition curves for glasses of the binary systems $\mathrm{Na}_{2} \mathrm{O}-\mathrm{SiO}{ }_{2}, \mathrm{~K}_{2} \mathrm{O}-\mathrm{SiO}_{2}$, and $\mathrm{Li}_{2} \mathrm{O}-\mathrm{SiO}_{2}$, exposed from 1 to 6 days to the humidity maintained by the aspirator procedure. The results obtained and the composition of these glasses are listed with the respective

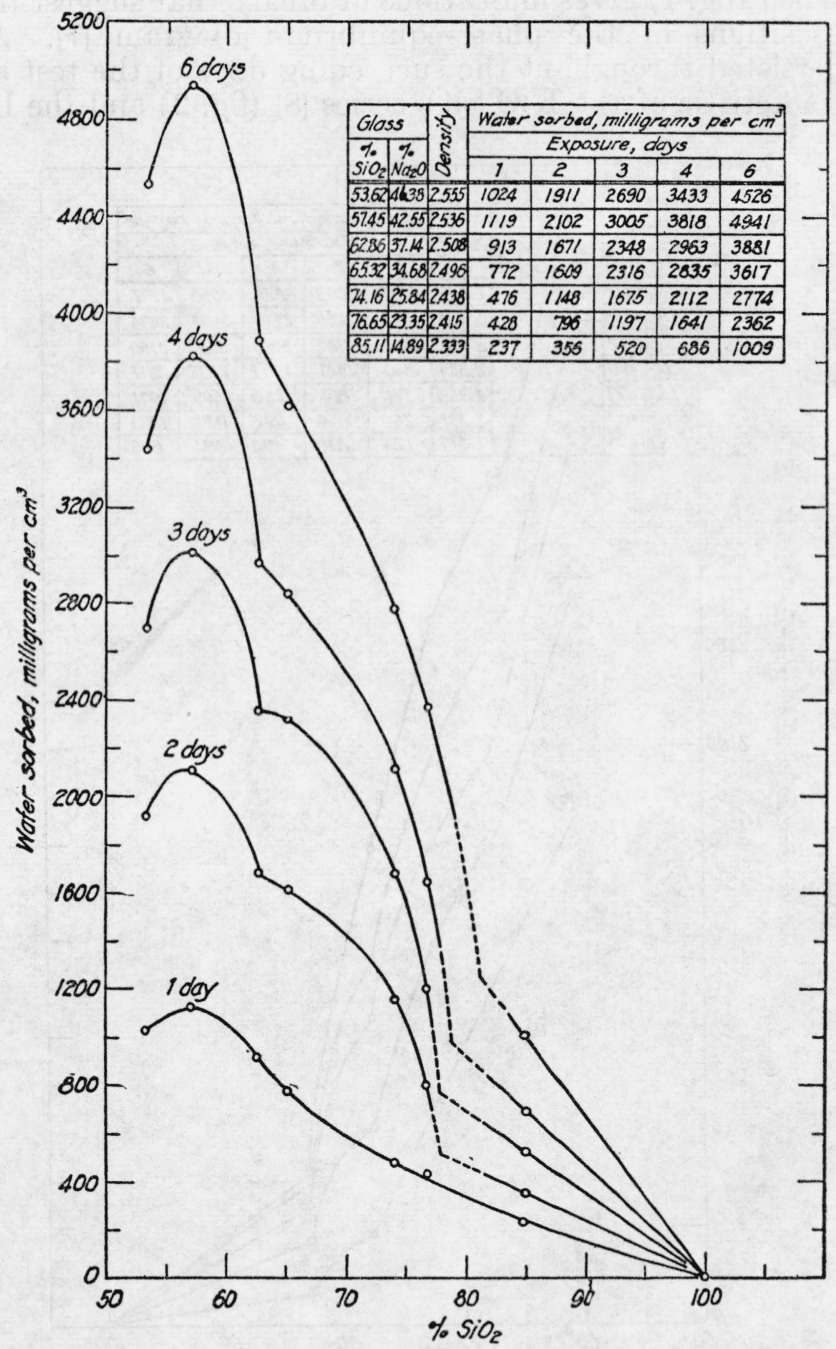

FiguRe 1.-Water sorbed by $\mathrm{Na}_{2} \mathrm{O}_{-} \mathrm{SiO}_{2}$ glasses as a function of their composition, after exposures of 1 to 6 days in the aspirator chamber.

- Analyses made by F. W. Glaze of glasses prepared by C. A. Faick. 
figures. All of the glasses of higher alkali content for the $\mathrm{Na}_{2} \mathrm{O}-\mathrm{SiO}_{2}$ and $\mathrm{K}_{2} \mathrm{O}-\mathrm{SiO}_{2}$ series became moist and some of them even went into solution. Nothing resembling an equilibrium value was attained after 6 days, indicating that true adsorption plays but a minor role and that absorption, reaction, and deliquescence are the predominating factors. The magnitude of the sorbed moisture correlates well with the known fact that the ability of these glasses to maintain a clear polished surface is very poor, but improves with increase in silica content.

For the $\mathrm{Na}_{2} \mathrm{O}-\mathrm{SiO}_{2}$ series, the curve for composition plotted against water sorbed (fig. 1) gives indications of breaks that suggest the eutectic compositions of the phase-equilibrium diagram [7]. As these breaks persisted throughout the succeeding days of the test and were also characteristic of the $\mathrm{K}_{2} \mathrm{O}-\mathrm{SiO}_{2}$ series [8] (fig. 2) and the $\mathrm{Li}_{2} \mathrm{O}-\mathrm{SiO}_{2}$

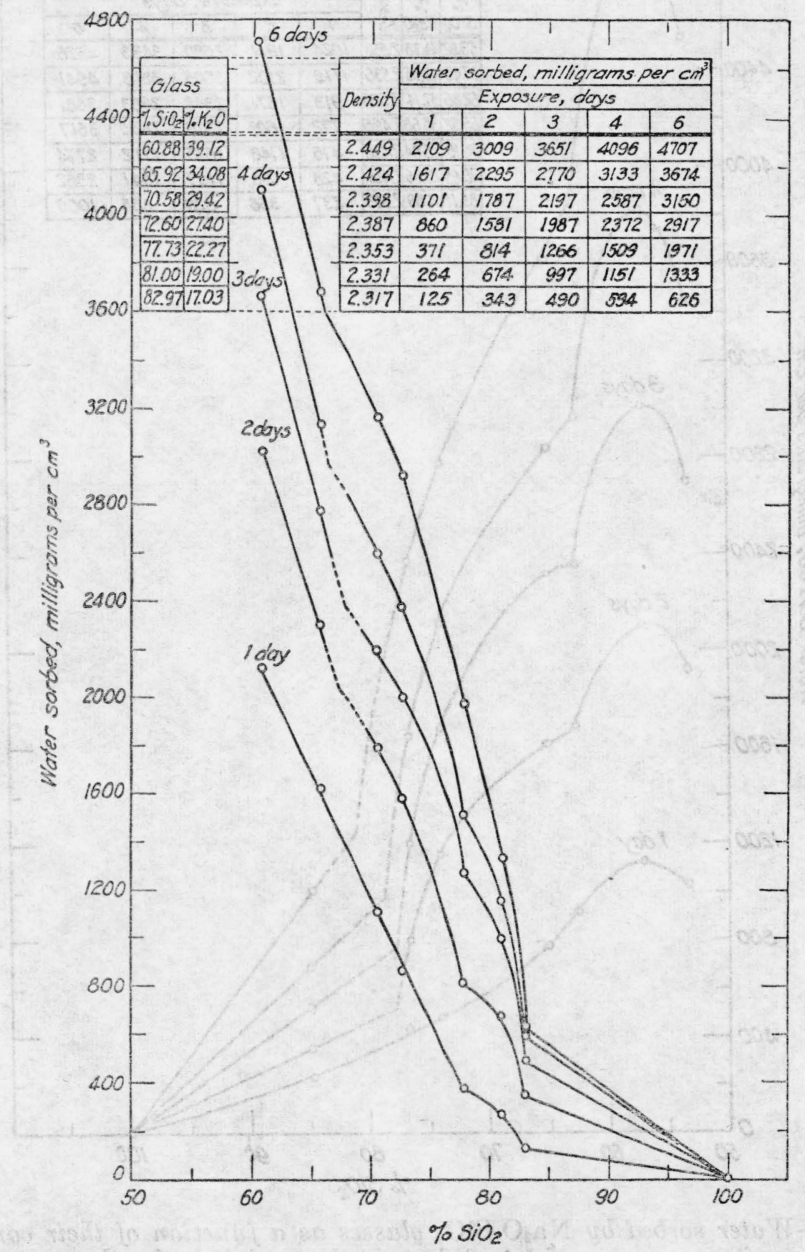

Figure 2.-Water sorbed by $\mathrm{K}_{2} \mathrm{O}-\mathrm{SiO}_{2}$ glasses as a function of their composition, afler exposures of 1 to 6 days in the aspirator chamber. 


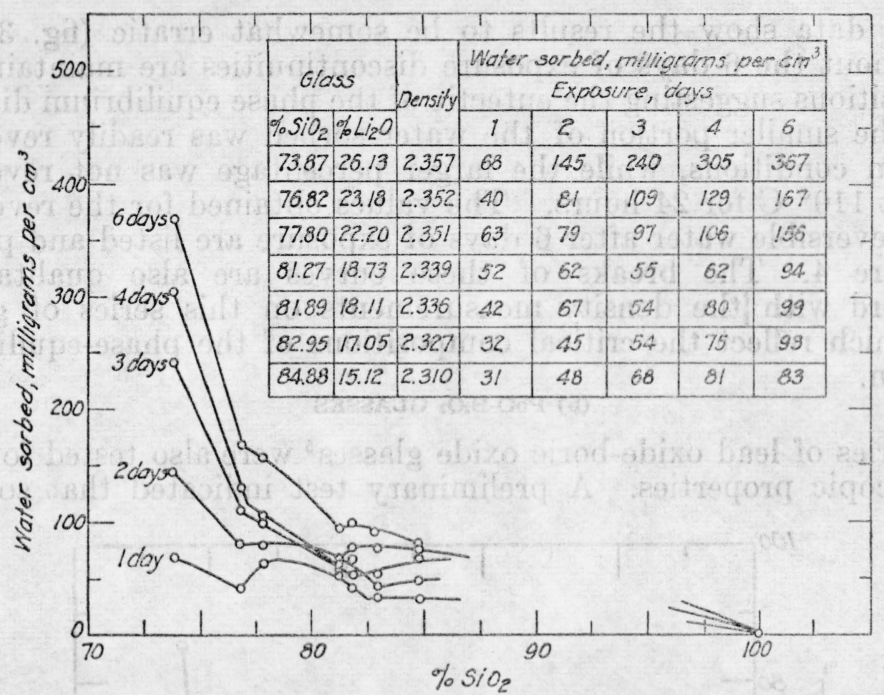

FIGURE 3.-Water sorbed by $\mathrm{Li}_{2} \mathrm{O}-\mathrm{SiO}_{2}$ glasses as a function of their composition, after exposures of 1 to 6 days in the aspirator chamber.

series [9], (fig. 3), it is probable that the results have some qualitative significance. This is further substantiated by the observation that the breaks indicated are essentially those shown by the more precise data for the densities of these same glasses published by F. W. Glaze and his colleagues $[10,11]$, and for index of refraction on the $\mathrm{Na}_{2} \mathrm{O}$ $\mathrm{SiO}_{2}$ glasses [12].

The $\mathrm{Li}_{2} \mathrm{O}-\mathrm{SiO}_{2}$ glasses sorbed much less water than did the $\mathrm{Na}_{2} \mathrm{O}-$ $\mathrm{SiO}_{2}$ and $\mathrm{K}_{2} \mathrm{O}-\mathrm{SiO}_{2}$ series, and, in fact are known to be far superior to the latter in their ability to maintain a clear surface. Although the

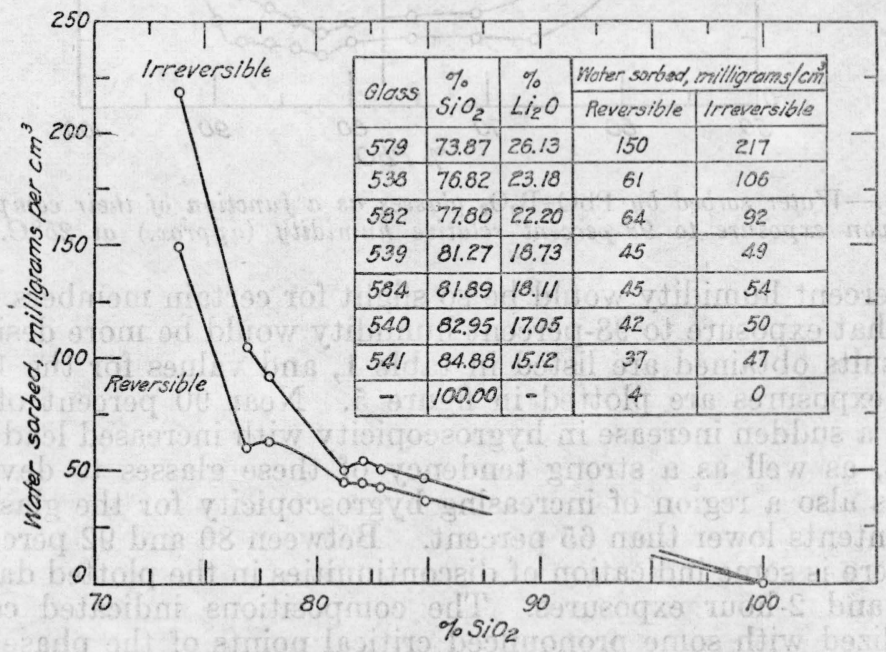

Figure 4.-Reversible and irreversible water for $\mathrm{Li}_{2} \mathrm{O}-\mathrm{SiO}_{2}$ glasses after 6 days of exposure in the aspirator chamber. 
plotted data show the results to be somewhat erratic (fig. 3), yet throughout the 6 days of exposure discontinuities are maintained at compositions suggesting the eutectic of the phase equilibrium diagram [9]. The smaller portion of the water sorbed was readily reversible at room conditions, while the larger percentage was not reversible even at $110^{\circ} \mathrm{C}$ for 24 hours. The values obtained for the reversible and irreversible water after 6 days of exposure are listed and plotted in figure 4. The breaks of these curves are also qualitatively in accord with / the density measurements on this series of glasses [11], which reflect the critica] compositions of the phase-equilibrium diagram.

\section{(b) $\mathrm{PbO}-\mathrm{B}_{2} \mathrm{O}_{3}$ GLASSES}

A series of lead oxide-boric oxide glasses ${ }^{5}$ were also tested for their hygroscopic properties. A preliminary test indicated that sorption

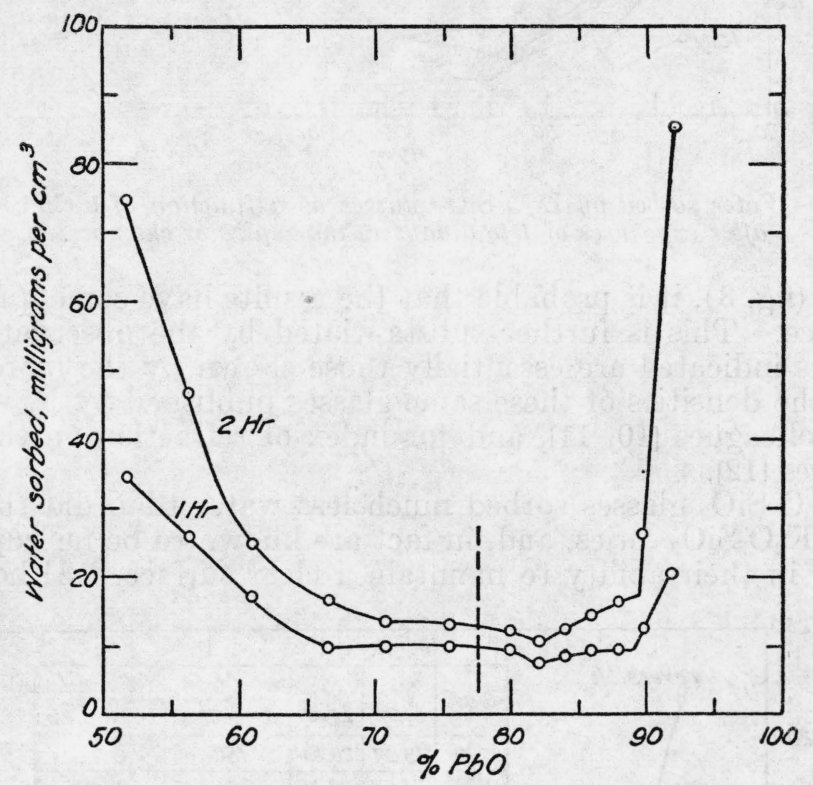

Figure 5.-Water sorbed by $\mathrm{PbO}-\mathrm{B}_{2} \mathrm{O}_{3}$ glasses as a function of their composition upon exposure to 98-percent relative humidity (approx.) at $25^{\circ} \mathrm{C}$.

at 95-percent humidity would be so slight for certain members of the group that exposure to 98-percent humidity would be more desirable. The results obtained are listed in table 1 , and values for the 1 - and 2-hour exposures are plotted in figure 5. Near 90 percent of $\mathrm{PbO}$ there is a sudden increase in hygroscopicity with increased lead oxide content, as well as a strong tendency of these glasses to devitrify. There is also a region of increasing hygroscopicity for the glasses at $\mathrm{PbO}$ contents lower than 65 percent. Between 80 and 92 percent of $\mathrm{PbO}$ there is some indication of discontinuities in the plotted data for the 1- and 2-hour exposures. The compositions indicated can be rationalized with some pronounced critical points of the phase equi-

S Prepared and analyzed by Leo Shartsis in partial fulfillment of the requirements for the degree of Master of Arts, George Washington University, February 1942. 
librium diagram [13]; however, the paucity of data and the complexity of the $\mathrm{PbO}-\mathrm{B}_{2} \mathrm{O}_{3}$ system make further evidence desirable. Not all the water sorbed by these glasses is reversible. The glasses of extremes in composition retain a large percentage of the water sorbed in 16 hours, with the glass of highest $\mathrm{PbO}$ content retaining the most.

TABLE 1.-Water sorbed $\left(\mathrm{mg} / \mathrm{cm}^{3}\right.$ by $\mathrm{PbO}-\mathrm{B}_{2} \mathrm{O}_{3}$ glasses at 98-percent relative humidity, $25^{\circ} \mathrm{C}$

\begin{tabular}{|c|c|c|c|c|c|}
\hline \multicolumn{2}{|c|}{ Glass } & \multirow{2}{*}{ Density ${ }^{1}$} & \multicolumn{2}{|c|}{$\begin{array}{l}\text { Water sorbed dur- } \\
\text { ing exposure for- }\end{array}$} & \multirow{2}{*}{$\begin{array}{c}\text { Irreversible } \\
\text { water (at } \\
110^{\circ} \mathrm{C} \text { ) after } \\
\text { 16-hr exposure }\end{array}$} \\
\hline $\mathrm{PbO}$ & $\mathrm{B}_{2} \mathrm{O}_{3}$ & & $1 \mathrm{hr}$ & $2 \mathrm{hr}$ & \\
\hline $\begin{array}{c}\text { Percent } \\
51.71 \\
56.25 \\
60.99 \\
66.50 \\
70.70 \\
75.50\end{array}$ & $\begin{array}{c}\text { Percent } \\
48.29 \\
43.75 \\
39.01 \\
33.50 \\
29.30 \\
24.50\end{array}$ & $\begin{array}{l}3.67 \\
3.97 \\
4.32 \\
4.76 \\
5.12 \\
5.56\end{array}$ & $\begin{array}{r}34.2 \\
25.9 \\
17.0 \\
9.7 \\
9.9 \\
9.7\end{array}$ & $\begin{array}{l}74.7 \\
46.8 \\
24.9 \\
16.6 \\
13.2 \\
13.0\end{array}$ & $\begin{array}{c}83.9 \\
2.6 \\
0.9 \\
\end{array}$ \\
\hline $\begin{array}{l}79.93 \\
82.08 \\
84.14 \\
85.98 \\
88.05 \\
89.86 \\
91.91\end{array}$ & $\begin{array}{r}20.07 \\
17.92 \\
15.86 \\
14.02 \\
11.95 \\
10.14 \\
8.09\end{array}$ & $\begin{array}{l}5.99 \\
6.21 \\
6.42 \\
6.62 \\
6.85 \\
7.05 \\
7.28\end{array}$ & $\begin{array}{r}9.3 \\
7.9 \\
8.4 \\
9.1 \\
9.5 \\
12.6 \\
20.6\end{array}$ & $\begin{array}{l}12.0 \\
10.8 \\
12.5 \\
14.3 \\
16.1 \\
26.1 \\
85.4\end{array}$ & $\begin{array}{r}2.0 \\
2.7 \\
4.2 \\
9.0 \\
35.5 \\
108.0\end{array}$ \\
\hline
\end{tabular}

1 Calculated by the equation $(\% \mathrm{PbO})^{2} / 1600+2=$ density [13].

\section{COMPARISON OF SOME TYPICAL OPTICAL AND OTHER COMMERCIAL GLASSES}

The results obtained on a group of typical glasses (composition, table 2) exposed to 95-percent relative humidity for 1-, 2-, 4-, and 16hour periods are listed and plotted in figure 6. As these glasses could not all be tested at one time, the glass from a dish that had failed to maintain a clear surface upon exposure to the atmosphere was included in both series. The samples for this glass were from independent screenings, and although they gave very satisfactory checks, they undoubtedly give an overly optimistic picture of reproducibility. Hence, for the purpose of ascertaining the serviceability of an unknown glass, it is necessary that reference glasses, such as the unsatisfactory dish and the satisfactory goblet, be included for comparison.

The most interesting feature of the results is the position occupied by the optical glasses. The hygroscopicity test compares them favorably with the better chemical laboratory glasswares, such as Pyrex, Tamworth, Kimble N-51-A, and fused silica, a position they do not achieve in chemical durability tests [1]. Yet this juxtaposition of these very dissimilar glasses serves well to emphasize that the ability of a glass to maintain a clear surface upon exposure to the atmosphere, and its chemical durability as conventionally determined are two inherently different properties.

The Corning 015 glass used so successfully for glass electrodes [14] exhibits a high sorbing capacity, which undoubtedly contributes to its low electrical resistance and other desirable electrical properties $[15$, p. 78]. The glasses of intermediate sorbing capacity, such as the American Ceramic Society bottle No. 1 [16] window glass, etc., show 
TABLE 2.-Compositions (in percent) of some optical and other glasses tested for hygroscopicity

[Calculated from batch compositions, unless otherwise noted]

\begin{tabular}{|c|c|c|c|c|c|c|c|c|c|c|c|c|c|c|c|}
\hline Glass & Density & $\mathrm{SiO}_{2}$ & $\mathrm{~B}_{2} \mathrm{O}_{3}$ & $\mathrm{P}_{2} \mathrm{O}_{5}$ & $\mathrm{Al}_{2} \mathrm{O}_{3}$ & $\mathrm{As}_{2} \mathrm{O}_{3}$ & $\mathrm{Sb}_{2} \mathrm{O}_{3}$ & $\mathrm{PbO}$ & $\mathrm{ZnO}$ & $\mathrm{CaO}$ & $\mathrm{MgO}$ & $\mathrm{BaO}$ & $\mathrm{K}_{2} \mathrm{O}$ & $\mathrm{Na}_{2} \mathrm{O}$ & $\mathrm{R}_{2} \mathrm{O}_{3}$ \\
\hline $\begin{array}{l}\text { Corning } 015[14,15] \\
\text { Dish a (failed in service) } \\
\text { Gobleta } \\
\text { Electric hygrometer [17] (soft-glass } \\
\quad \text { tubing) }\end{array}$ & $\begin{array}{l}2.5 \\
2.5 \\
2.8 \\
2.5\end{array}$ & $\begin{array}{l}72.0 \\
72.7 \\
66.1\end{array}$ & 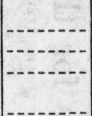 & 0.1 & 0.5 & 0.1 & 0.2 & 17.2 & & $\begin{array}{l}6.0 \\
9.3\end{array}$ & & $\begin{array}{l}0.4 \\
1.4\end{array}$ & 9.7 & $\begin{array}{r}22.0 \\
16.7 \\
5.6\end{array}$ & - \\
\hline Am. Ceram. Soc. bottle No.1[16] & 2.5 & 73.3 & Present & & 1.1 & & - no & & 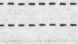 & 4.8 & 3.3 & 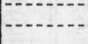 & 16. & 7 & (n) \\
\hline $\begin{array}{l}\text { Window glass } \\
\text { Blue bottle } \\
\text { BSC } 517 \\
\text { F } 620 \\
\mathrm{PbO}-\mathrm{B}_{2} \mathrm{O}_{3} \mathrm{~b}_{\mathrm{b}}\end{array}$ & $\begin{array}{l}2.5 \\
2.5 \\
2.5 \\
3.6 \\
3.67\end{array}$ & $\begin{array}{l}72.1 \\
77.5 \\
66.4 \\
45.6 \\
\end{array}$ & $\begin{array}{r}0.5 \\
12.4 \\
48.3\end{array}$ & & 3.5 & $\begin{array}{l}.5 \\
.5\end{array}$ & (n) & $\begin{array}{l}45.1 \\
51.7\end{array}$ & 0.5 & 10.0 & 3.3 & 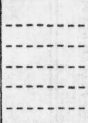 & $\begin{array}{r}11.8 \\
5.2\end{array}$ & $\begin{array}{r}13.5 \\
8.4 \\
3.6\end{array}$ & \begin{tabular}{r}
0.7 \\
\hdashline-1 \\
-0
\end{tabular} \\
\hline $\begin{array}{l}\text { BaC } 572 \\
\text { Pyrex } \\
\text { Fused silica- }\end{array}$ & $\begin{array}{l}\text { 3. } 20 \\
2.23 \\
2.21\end{array}$ & $\begin{array}{r}49.7 \\
81.0 \\
100\end{array}$ & $\begin{array}{r}3.6 \\
13.0\end{array}$ & & & $\begin{array}{l}.2 \\
.002\end{array}$ & .4 & -....... & 7.2 & - n & & 30.8 & $\begin{array}{r}7.7 \\
.2\end{array}$ & $\begin{array}{r}.4 \\
3.6\end{array}$ & 2.2 \\
\hline
\end{tabular}

- Glasses furnished by A. E. Williams.

b Analysis made by Leo Shartsis. 


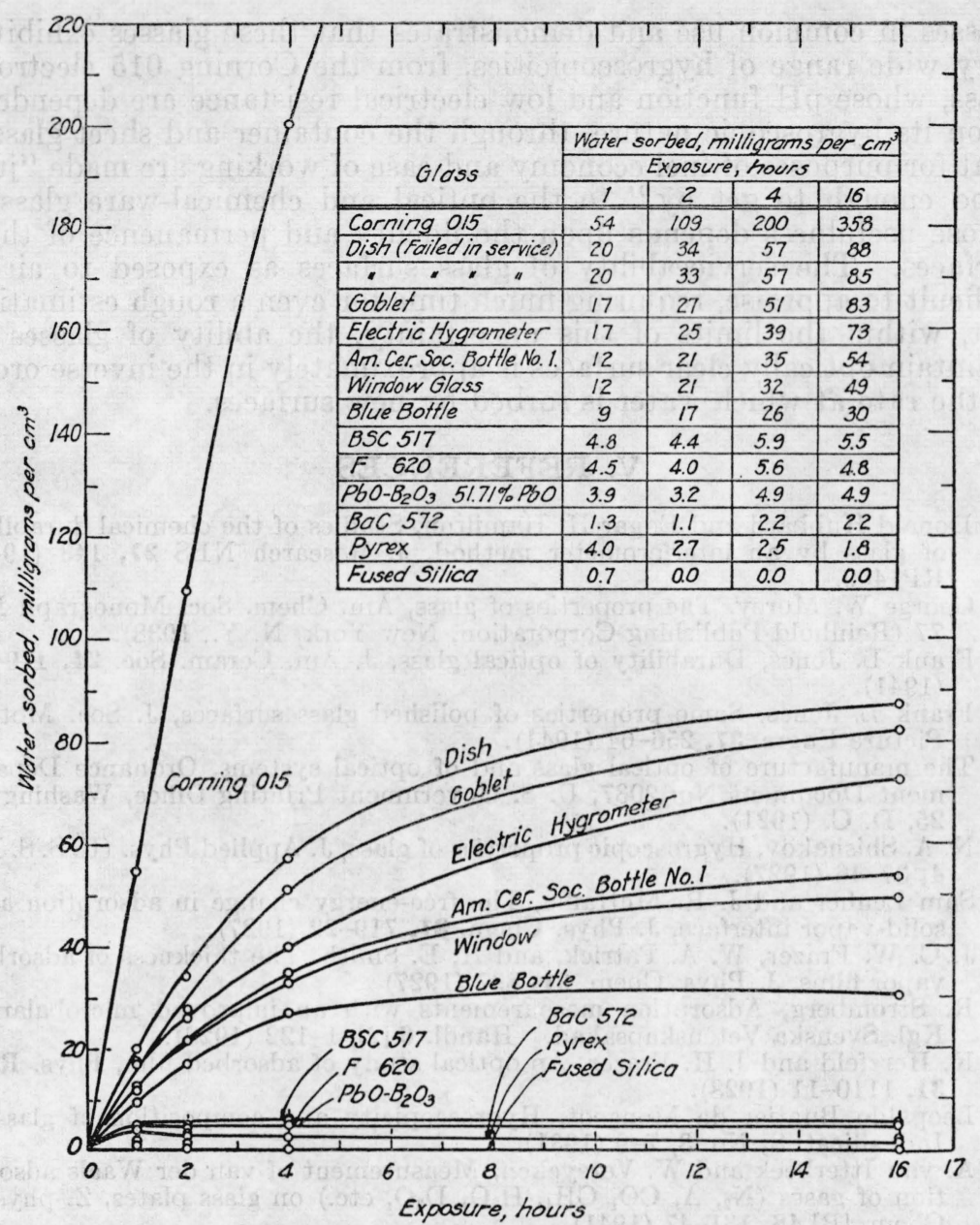

FIGURE 6.-Comparison of optical and commercial glasses exposed to 95-percent relative humidity (approx.) at $25^{\circ} \mathrm{C}$.

reasonably satisfactory performance as glass electrodes but are not nearly so sensitive as the 015 glass. Further, the glasses that have very low sorption values are completely unsatisfactory for general glass electrode work, for example, the BaC 572, F 620, BSC 517, Pyrex, and fused silica.

\section{CONCLUSIONS}

The powder hygroscopicity method has been tried on glasses covering a wide range of compositions and industrial uses. It offers considerable promise as a pertinent test for the serviceability of optical glasses, i. e., the ability to maintain a clear surface upon exposure to the atmosphere. It also possesses the unique advantages of simplicity and speed of determination. It readily differentiates between the 


\section{Journal of Research of the National Bureau of Standards}

glasses in common use and demonstrates that these glasses exhibit a very wide range of hygroscopicities, from the Corning 015 electrode glass, whose $\mathrm{pH}$ function and low electrical resistance are dependent upon its hygroscopic nature, through the container and sheet glasses that for purposes of fuel economy and ease of working are made "just good enough to get by," to the optical and chemical-ware glasses, whose usefulness depends upon the fidelity and permanence of their surfaces. The serviceability of glass surfaces as exposed to air is difficult to appraise, requiring much time for even a rough estimation but, within the limits of this uncertainty, the ability of glasses to maintain optically clear surfaces is approximately in the inverse order to the rate at which water is sorbed by new surfaces.

\section{REFERENCES}

[1] Donald Hubbard and Edgar H. Hamilton, Studies of the chemical durability of glass by an interferometer method, J. Research NBS 2\%, 143 (1941) RP1409.

[2] George W. Morey, The properties of glass, Am. Chem. Soc. Monograph No. 77 (Reinhold Publishing Corporation, New York, N. Y., 1938).

[3] Frank L. Jones, Durability of optical glass, J. Am. Ceram. Soc. 24, 119-22 (1941).

Frank L. Jones, Some properties of polished glass surfaces, J. Soc. Motion Picture Engrs. 3\%, 256-64 (1941).

The manufacture of optical glass and of optical systems, Ordnance Department Document No. 2037, U. S. Government Printing Office, Washington 25 , D. C. (1921).

[4] N. A. Shishakov, Hygroscopic properties of glass, J. Applied Phys. (U. S. S. R.) 4, $37-46$ (1927).

Sam Lenher and J. R. McHaffie, The free-energy change in adsorption at a solid-vapor interface, J. Phys. Chem. 31, 719-22 (1927).

J. C. W. Frazer, W. A. Patrick, and H. E. Smith, The thickness of adsorbed vapor films, J. Phys. Chem. 31, 897 (1927).

R. Stromberg, Adsorption measurements with an improved microbalance, Kgl. Svenska Vetenskapsakad. Handl. 6 [2], 1-122 (1928).

K. Herzfeld and J. H. Frazer, An optical study of adsorbed film, Phys. Rev. 31, $1110-11$ (1928).

Leopaldo Buatier de Mongeot, Hygroscopicity and composition of glasses, Ind. silicati 8, No. 3, 7-9 (1931).

A. van Itterbeek and W. Vereycken, Measurement of van der Waals adsorption of gases $\left(\mathrm{N}_{2}, \mathrm{~A}, \mathrm{CO}, \mathrm{CH}_{4}, \mathrm{H}_{2} \mathrm{O}, \mathrm{D}_{2} \mathrm{O}\right.$, etc.) on glass plates, $\mathrm{Z}$. physik. Chem. [B] 48, 131-47 (1941).

H. Menzel and S. Sliwinski, Studies on the system $\mathrm{Li}_{2} \mathrm{O}-\mathrm{BeO}-\mathrm{B}_{2} \mathrm{O}_{3}, \mathrm{Z}$. anorg. allgem. Chem. 249, 337-385 (1942).

Stephen Brunauer, The adsorption of gases and vapors, 1 (Princeton University Press, 1943).

[5] James W. McBain, The mechanism of the adsorption ("sorption") of hydrogen on carbon, Phil. Mag. [6] 18, 916 (1909); Z. physik. Chem. 68, 471 (1909).

[6] Herbert Freundlich, Colloid and capillary chemistry, English translation

* (E. P. Dutton \& Co., Inc., New York, N. Y.).

[7] F. C. Kracek, The system sodium oxide-silica, J. Phys. Chem. 34, 1583 (1930); J. Am. Ceram. Soc. 16, 491 (1933).

[8] F. C. Kracek, N. L. Bowen, and G. W. Morey, The system potassium meta

silicate-silica, J. Phys. Chem. 33, 1857 (1929); J. Am. Ceram. Soc. 16, 490 (1933).

[9] F. C. Kracek, The binary system lithium oxide-silica, J. Phys. Chem. 34, 2641 (1930); J. Am. Ceram. Soc. 16, 491 (1933).

[10] F. W. Glaze, J. C. Young, and A. N. Finn, The density of some soda-limesilica glasses as a function of the composition, BS J. Research 9, 799 (1932) RP507. 
[11] J. C. Young, F. W. Glaze, C. A. Faick, and A. N. Finn, Density of some soda-potash-silica glasses as a function of the composition, J. Research NBS 22, 453 (1939).

[12] C. A. Faick and A. N. Finn, The index of refraction of some soda-lime-silica glasses as a function of the composition, J. Am. Ceram. Soc. 14, 518 (1931).

[13] R. F. Geller and E. N. Bunting, The system $\mathrm{PbO}-\mathrm{B}_{2} \mathrm{O}_{3}$, J. Research NBS 18, 585 (1937) RP995.

[14] D. A. MacInnes and M. Dole, The behavior of glass electrodes of different compositions, J. Am. Chem. Soc. 52, 29-36 (1930).

[15] Malcolm Dole, The glass electrode (John Wiley \& Sons, Inc., New York, N. Y., 1941).

[16] Report of Committee on the Chemical Durability of Glass, Bul. Am. Ceram. Soc. 14, 181 (1935).

[17] Francis W. Dunmore, An electric hygrometer and its application to radio meteorography, J. Research NBS 20, 723 (1938) RP1102.

Washington, December 19, 1945. 